\title{
A study of the impacts of leverage on labor and capital productivity: A case study of companies listed in Tehran Stock Market
}

\author{
Peyman Akbari $^{a^{*}}$ and Ehsan Mohammadi ${ }^{\mathrm{b}}$
}

\begin{abstract}
${ }^{a}$ Master of Commercial Management, Young Researchers Club, Kermanshah Branch, Islamic Azad University, Kermanshah, Iran ${ }^{b}$ Master Student of Accounting, Islamic Azad University, Hamedan Branch, Hamedan, Iran

\section{H R O N I C L E \\ A B S T R A C T}

Article history:

Received October 20, 2012

Received in revised format

5 January 2013

Accepted 15 January 2013

Available online

January 182013

Keywords:

Operating Leverage

Financial Leverage

Compound Leverage

Labor Productivity

Capital Productivity

Productivity is a primary objective of increasing competition in modern economy and any increase in productivity level helps development of organization in the competitive market. The purpose of this paper is to investigate the relationship between operating leverage, financial leverage, compound leverage as independent variables and productivity indices including labor and capital productivities as dependent variables. The study includes 102 companies accepted in Tehran Stock Market based on screening, systematic deletion, over the period 2005-2010. The required data are gathered through official financial statements, committee reports, and other available documents in Tehran Stock Market. Stepwise regression and Pearson correlation are used to analyze the data. The results of the study have indicated that there were significant relationships between independent variables including leverage ratios with labor productivity. In addition, there is also a significance relationship between leverage ratios with capital productivity of total assets.
\end{abstract}

\section{Introduction}

During the past few years, there have been growing interests on development of business units through privatization in many countries around the world. Privatization helps build a more diversified group of shareholders and there will be more responsibility for boards of directors to increase profitability by making better decisions and improving efficiency of the firms (Akbari, 2010a). Productivity plays an important role on increasing profitability of organizations (Ansari \& Karimi, 2009). In fact, when there is no appropriate method for measuring the relative efficiency of organizations, we may not be able to have a good idea of stock price evaluation and management cannot be evaluated, properly (Shariatpanahi \& Badavanahandi, 2004). Hence, performance management plays essential role for company's shareholders too.

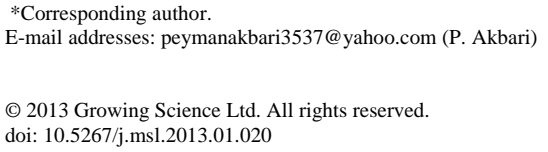


Performance measurement is the basis of many decisions such spin off, take over, etc. In addition, creditor, investors, governments and even the managers, also considers companies' performance evaluation. Creditors need performance measurement for giving appropriate rates for loans, while investors are interested in evaluating management success for the implementation of their investment. The most important aspect that should be considered by investors in evaluating performance is whether the surplus value has been created for them or not? In other words, the value of their investment, resulting in management performance has been increased or not? On other hand, it is an essential fact for companies to have good performance in reasonable amount of time and increase shareholders' wealth is the most important objective (Akbari, 2010b).

Therefore, this paper attempts to evaluate surplus value and to calculate productivity and the relationship between productivity and leverage ratio. Since the productivity in organizations is enumerated as the primary purpose and promotion, any improvement in productivity could help managers improve their performance. The survival of organizations is associated with growth and productivity. It is also necessary to understand the correlation between productivity and leverage ratios.

\section{Theoretical Principles of Research History}

\subsection{Productivity}

For years, productivity has been the most important issues among organizations and a significant amount of research has been devoted to this topic. It is also important macro economy factor considered in country level in addition to other important factors inflation, unemployment, economic conditions of society and competition in international level. Productivity is considered along with other factors such as increasing competition, technological complexity, lack of resources and the rate of information exchange. Productivity has been synonymous with the organization rationalism, rational behavior, and most managers consider different knowledge management techniques to increase productivity. Productivity is also used for comparing the performance of institutions with similar structure.

Productivity beyond an evaluation criterion, expressed as a culture of attitude to work and life and enhancing its origin in the various aspects of development to reach organization and individuals' needs. Productivity is highly beneficial to a nation, industry, companies and individuals. Productivity increases Gross Domestic Product and competitiveness and improves the quality of life (Akbari, 2010a). Productivity, on the one hand, reduces prices and increases shareholders' profits. There are different perceptions on the concept of productivity. While some managers consider productivity only in terms of profitability figure, others look at accomplishing tasks more effectively (Akbari, 2010b). Productivity is defined as the relationship between the amounts of product obtained in a certain time the total amount of factors spent during production. In other words, the relationship between input and output is called productivity when this relationship is compared with the level of productivity in the base period, productivity index can also be computed. Productivity indicators are divided into the following four categories,

Partial productivity index: Examples include labor productivity, personnel costs, capital, value of materials, energy. The most important indicators are of labor productivity and capital (Akbari, 2010c).

$>$ Total productivity index: it is obtained by dividing the total value of productive product (output) to the total value of all used inputs. Total productivity is a criterion, which is common among all inputs such as labor, materials and components, machinery (Azarbaeijani et al, 2007). 
$>$ Total factors productivity index productivity: total factors of production productivity are achieved by ratio of surplus value on cumulative total value of used inputs such as labor and capital (Akbari, 2010c).

> Comprehensive productivity index: This index is the most complex criterion, in calculating productivity that broadens the concept of productivity index (Samantha \& Enserch, 1991).

According to Kendrick (1993) in companies and organizations where the relative productivity is higher than the industry average, productivity generally leads to higher profit margins as well. In addition, if the company's productivity increases faster than its competitors the company will also increase its profit margins more quickly. Organizations where their productivity is lower than the average productivity the industry and their productivity rates is less than competing companies eventually will be bankrupted (Kendrick, 1993).

Forastic (1975) emphasized on humanities and social importance of high productivity. The purpose of this study is to describe the relationship between operating leverage, financial, combined with productivity indicators. Therefore, the research with extensive studying and comprehensive survey seeks to answer this question: Is there a significant relationship between the leverage ratio, operational, financial, and combined, on the one hand and indicators of productivity, labor and capital, on the other hand or not?

\subsection{Research Literature}

There have been significant contributions on productivity indicators in various economic sectors in the world (Akbari, 2010; Rezai et al., 2009; Tehrani \& Khojasteh, 2008; Etmady et al., 2009; Baharestan, 2007; Sinai \& Ahmadi, 2003; Eling \& Michael, 2009; Rudolf \& Zurlinden, 2009; Van der Eng, 2009; Lopez \& Chacon, 2009; Vial, 2008; Davis \& Madsen, 2008; Brown \& Rowe, 2007). However, to the best of our knowledge, no research has been associated with the proposed study of this paper.

Akbari (2010) examined the relationship between changes in performance indicators, based on productivity, labor productivity and capital productivity, and changes in financial variables including earnings per share, book value of shares, market value of shares in companies adopted in Tehran stock Exchange over the period 2004-2008 with a sample of 102 members. The researcher found that there was a relationship between changes in performance indicators based on productivity and changes in financial variables.

Rezaei et al. (2009) assessed changes in total productivity of production factors in the Tehran Stock Exchange by using the index Tornqvist index and found that the productivity of production factors in Tehran Stock Exchange on average was faced with 0.902 percent growth, which was far from with the government's goals. Tehrani and Khojasteh (2008) investigated the relationship between capital productivity and its effect on future stock returns valuable and growth investment strategies, in a sample of 85 members of companies listed in Tehran Stock Exchange. They found some relationship between capital productivity and future stock returns in two modes of general and controlled variables and confirmed the significant effect of this relationship on improving the efficiency of both valuable and growth strategies.

Etmady et al. (2007) investigated the relationship between manpower and stock return of companies in Tehran Stock Exchange over the period 2001-2005 with a sample of 112 members. They reported that there was no significant relationship between manpower productivity and stock returns of companies in Tehran Stock Exchange and there was no difference between capital-intensive, and labor-intensive companies. Continued effect of type of industry on this relationship was examined 
and the results were obtained that this was negatively related in six industries. Baharestan (2006) investigated the relationship between accounting variables (sales, Actual Cost of goods sold, gross profit and operating costs) and productivity indicators (labor and capital), at production companies listed in Tehran Stock Exchange with a sample of 122 paid members over the period 2000-2004. They found that there was a relationship between accounting variables and indicators of labor and capital productivity.

Sinai and Ahmadi (2003) examined the relationship between measures of productivity (labor and capital) and profitability index (the ratio of return on assets the ratio of return on stockholders and ratio of return of the sale), in public company of food and beverage groups listed in Tehran stock Exchange over the period 1996-2000 with a sample of 27-member. They found that there was a relationship between productivity of labor and profitability indicators, but there was no relationship between capital productivity and profitability indicators.

Eling and Michael (2009) evaluated the relative efficacies of 6462 firms from 36 countries based on different methods, countries, organizational form and size of the company and, living and dead insured, in the international insurance industry. Researchers found that a growth in cost efficiency, and technical was observed in international insurance markets over the period 2002-2006. In their study, Denmark and Japan had the highest average of efficiency, while the Filipinos were in the least level. Rudolf and Zurlinden (2009) evaluated the productivity and economic growth in Switzerland over the period 1991-2005 and reported that the growth in labor and capital were 0.57 and 0.45 , respectively. This estimated growth in multi-factor was lower than in previous studies because our standard of work, had variations in quality. Lopez and Chacon (2009) investigated theoretical sources of productivity growth in Japan, America and Germany and found that these technology resources were divided into mutual development as a particular investment. Vial (2008) studied productivity growth in Indonesian manufacturing industries. The researcher found that the manufacturing industry had a double structure composed of small and large companies. This combination included companies with small size, medium and large played an important role in Indonesia's dynamics economy. Davis and Madsen (2008) examined the relationship among various indicators of productivity with return on stocks of 11 industrialized development countries. Researchers found that there was a big difference among various indicators of productivity in explaining stock returns. Brown and Rowe (2007) examined the productivity of 1000 top companies in US Exchange over the period 1970-2005.

\subsection{Research hypotheses}

In this study, the leverage ratios including operational, financial, composed leverage are defined as the independent variables. In addition, indicators of productivity including labor productivity of personnel number and personnel cost, capital productivity of fixed assets and total assets are dependent variables research. There is one main hypothesis and six sub-hypothesis that each subhypothesis in turn includes two other hypotheses as follows. In addition, the research hypotheses have been tested in three modes: 1 - adjusted by the wholesale price index of goods and services 2 - nonadjusted 3 - adjusted by inflation index. The base year, is the year 2005 that its index number is 100 (Central Bank of Iran, 2008).

The main hypothesis states that there is a significant relationship between Operating Leverage, Financial Leverage, Compound Leverage, productivity Indexes.

The other research hypotheses are as follows:

1) There is a significant relationship between Operating Leverage and Labor productivity.

2) There is a significant relationship between Financial Leverage and Labor productivity.

3) There is a significant relationship between Compound Leverage and Labor productivity. 
4) There is a significant relationship between Operating Leverage and Capital productivity.

5) There is a significant relationship between Financial Leverage and Capital productivity.

6) There is a significant relationship between Compound Leverage and Capital productivity.

\section{Table 1}

Theoretical \& operational definition of project variables

\begin{tabular}{|c|c|c|c|}
\hline $\begin{array}{l}\text { Name of } \\
\text { variable }\end{array}$ & $\begin{array}{l}\text { Type of } \\
\text { variable }\end{array}$ & Theoretical Definition of variable & $\begin{array}{l}\text { Operational Definition of } \\
\text { variable }\end{array}$ \\
\hline $\begin{array}{l}\text { Operating } \\
\text { Leverage }\end{array}$ & Independent & $\begin{array}{l}\text { It shows percentage change in earnings before interest and } \\
\text { taxes against one percent change in sales. }\end{array}$ & $O L=\frac{Q(P-V)}{Q(P-V)-F}$ \\
\hline $\begin{array}{l}\text { Financial } \\
\text { Leverage }\end{array}$ & Independent & $\begin{array}{l}\text { It shows, percentage change in earnings per share against one } \\
\text { percent change in earnings before interest and taxes }\end{array}$ & $F L=\frac{S-F-V C}{S-F-V C-I-\frac{E}{1-t}}$ \\
\hline $\begin{array}{l}\text { Compound } \\
\text { Leverage }\end{array}$ & Independent & $\begin{array}{l}\text { It shows the rate of change in earnings per share against one } \\
\text { percent change in sales. }\end{array}$ & $C L=\frac{S-V C}{S-F-V C-I-\frac{E}{1-t}}$ \\
\hline $\begin{array}{l}\text { Labor } \\
\text { productivity }\end{array}$ & Dependent & $\begin{array}{l}\text { Amount of output of the organization is for each Rial paid to } \\
\text { labor force, or per person of labor force. }{ }^{1}\end{array}$ & $\begin{array}{l}L . P . P=\frac{V \cdot A}{N \cdot P} \\
L . E . P=\frac{V \cdot A}{E \cdot P}\end{array}$ \\
\hline $\begin{array}{l}\text { Capital } \\
\text { productivity }\end{array}$ & Dependent & $\begin{array}{c}\text { Amount of organization's output has been used for each Rial } \\
\text { asset. }\end{array}$ & $\begin{array}{l}C . F \cdot A \cdot P=\frac{V \cdot A}{T \cdot F \cdot A} \\
C . T \cdot A \cdot P=\frac{V \cdot A}{T \cdot A}\end{array}$ \\
\hline
\end{tabular}

\section{Research Methodology}

This research is an applied research. According to the types of variables, the research is descriptive in which the relationship among variables will be explored using regression and correlation coefficient equations. The related data for testing the hypothesis will be collected from Tehran stock markets, annual data sheets, explanatory remarks of accepted companies in Tehran stock markets, including data sheet, benefit and lost, board of managers' reports and software showing financial information of companies. The study covers the period of six years. The collected data from Tehran stock market will be saved in data bank software such as Excel (field study). Pearson correlation will be used to find any relationship among the variables. Moreover, to assess the impact of each variable on dependent variable stepwise regression analysis will be applied. The least square with confidence level of 0.095, $R^{2}$ coefficient, normalized $\bar{R}^{2}$ and $\mathrm{P}$ size is used. If $\mathrm{P}$-value $<0.05$, then directional hypothesis approved otherwise the null hypothesis is approved. SPSS and Excel software's will be applied for presenting tables and analysis of data. The statistical sample of this study will include all companies accepted in Tehran stock markets. Sample size will be selected according to the four following criteria and systematic deletion rule based on screening financial lists:

1. The financial lists data will be available for the period of Six years (2005-2010).

2. The financial year for each 12 months period had been determined.

3. The under study companies be active at least for the last six months.

4. The under study companies are not investment companies.

Note: brokers and investing companies will not be considered in this study.

${ }^{1}$. The surplus value is one of the accounting concepts and by using of this criterion, the value of any one of assets items, will be determined based on historical data. And for calculating it in this study is used sum method, and the its formula is as follows:

Workforce cost + tax + Interest + Depreciation + net profit $=$ Surplus Value 


\section{The research results}

Table 2 to Table 7 summarize the Pearson correlation ratios between different components.

Table 2

Pearson correlation results on wholesale price index

\begin{tabular}{ccccccc}
\hline \multirow{2}{*}{ Hypothetical } & \multicolumn{2}{c}{ Hypothesis 1 } & \multicolumn{2}{c}{ Hypothesis 2 } & \multicolumn{2}{c}{ Hypothesis 3 } \\
\cline { 2 - 7 } & $\begin{array}{c}\text { Personnel } \\
\text { cost }\end{array}$ & $\begin{array}{c}\text { Personnel } \\
\text { number }\end{array}$ & personnel cost & $\begin{array}{c}\text { Personnel } \\
\text { number }\end{array}$ & $\begin{array}{c}\text { personnel cost } \\
\text { number }\end{array}$ \\
\hline Type of Relationship & Linear & Linear & Linear & Linear & Linear & Linear \\
\hline Std. Error & 0.05 & 0.05 & 0.05 & 0.05 & 0.05 & 0.05 \\
$\mathrm{~N}$ & 102 & 102 & 102 & 102 & 102 & 102 \\
$\mathrm{R}$ & 0.004 & 0.014 & -0.256 & -0.216 & -0.058 & -0.030 \\
$\mathrm{R}^{2}$ & 0.00001 & 0.0001 & 0.065 & 0.046 & 0.003 & 0.0009 \\
P-value & 0.484 & 0.443 & 0.005 & 0.015 & 0.280 & 0.381 \\
Confidence Interval & 0.095 & 0.095 & 0.095 & 0.095 & 0.095 & 0.095 \\
\hline Hypothesis Verification & $\mathrm{H}_{0}$ & $\mathrm{H}_{0}$ & $\mathrm{H}_{1}$ & $\mathrm{H}_{1}$ & $\mathrm{H}_{0}$ & $\mathrm{H}_{0}$ \\
\hline
\end{tabular}

Table 3

Pearson correlation results on wholesale price index

\begin{tabular}{ccccccc}
\hline \multirow{2}{*}{ Hypothetical } & \multicolumn{2}{c}{ Hypothesis 4} & \multicolumn{2}{c}{ Hypothesis 5} & \multicolumn{2}{c}{ Hypothesis 6 } \\
\cline { 2 - 7 } & fixed assets & total assets & fixed assets & total assets & fixed assets & total assets \\
\hline Type of Relationship & Linear & Linear & Linear & Linear & Linear & Linear \\
\hline Std. Error & 0.05 & 0.05 & 0.05 & 0.05 & 0.05 & 0.05 \\
$\mathrm{~N}$ & 102 & 102 & 102 & 102 & 102 & 102 \\
$\mathrm{R}$ & 0.000 & -0.017 & -0.037 & -0.053 & 0.000 & -0.058 \\
$\mathrm{R}^{2}$ & 0.000 & 0.0002 & 0.001 & 0.002 & 0.000 & 0.003 \\
P-value & 0.499 & 0.432 & 0.357 & 0.299 & 0.499 & 0.283 \\
Confidence Interval & 0.095 & 0.095 & 0.095 & 0.095 & 0.095 & 0.095 \\
\hline Hypothesis Verification & $\mathrm{H}_{0}$ & $\mathrm{H}_{0}$ & $\mathrm{H}_{0}$ & $\mathrm{H}_{0}$ & $\mathrm{H}_{0}$ & $\mathrm{H}_{0}$ \\
\hline
\end{tabular}

\section{Table 4}

Pearson correlation results of no adjustment

\begin{tabular}{ccccccc}
\hline \multirow{2}{*}{ Hypothetical } & \multicolumn{2}{c}{ Hypothesis 1 } & \multicolumn{2}{c}{ Hypothesis 2 } & \multicolumn{2}{c}{ Hypothesis 3 } \\
\cline { 2 - 7 } & $\begin{array}{c}\text { Personnel } \\
\text { cost }\end{array}$ & $\begin{array}{c}\text { Personnel } \\
\text { number }\end{array}$ & Personnel cost & $\begin{array}{c}\text { Personnel } \\
\text { number }\end{array}$ & $\begin{array}{c}\text { Personnel cost } \\
\text { Personnel } \\
\text { number }\end{array}$ \\
\hline Type of Relationship & Linear & Linear & Linear & Linear & Linear & Linear \\
\hline Std. Error & 0.05 & 0.05 & 0.05 & 0.05 & 0.05 & 0.05 \\
N & 102 & 102 & 102 & 102 & 102 & 102 \\
$\mathrm{R}$ & 0.026 & 0.039 & -0.241 & -0.221 & -0.075 & -0.030 \\
$\mathrm{R}^{2}$ & 0.0006 & 0.001 & 0.058 & 0.048 & 0.005 & 0.0009 \\
P-value & 0.399 & 0.350 & 0.007 & 0.013 & 0.285 & 0.381 \\
Confidence Interval & 0.095 & 0.095 & 0.095 & 0.095 & 0.095 & 0.095 \\
\hline Hypothesis Verification & $\mathrm{H}_{0}$ & $\mathrm{H}_{0}$ & $\mathrm{H}_{1}$ & $\mathrm{H}_{1}$ & $\mathrm{H}_{0}$ & $\mathrm{H}_{0}$ \\
\hline
\end{tabular}

Table 5

Pearson correlation results of no adjustment

\begin{tabular}{ccccccc}
\hline \multirow{2}{*}{ Hypothetical } & \multicolumn{2}{c}{ Hypothesis 4 } & \multicolumn{2}{c}{ Hypothesis 5 } & \multicolumn{2}{c}{ Hypothesis 6 } \\
\cline { 2 - 7 } & fixed assets & total assets & fixed assets & total assets & fixed assets & total assets \\
\hline Type of Relationship & Linear & Linear & Linear & Linear & Linear & Linear \\
\hline Std. Error & 0.05 & 0.05 & 0.05 & 0.05 & 0.05 & 0.05 \\
$\mathrm{~N}$ & 102 & 102 & 102 & 102 & 102 & 102 \\
$\mathrm{R}$ & -0.041 & 0.042 & 0.031 & 0.239 & 0.035 & 0.424 \\
$\mathrm{R}^{2}$ & 0.001 & 0.001 & 0.0009 & 0.057 & 0.001 & 0.018 \\
P-value & 0.342 & 0.339 & 0.378 & 0.008 & 0.362 & 0.000 \\
Confidence Interval & 0.095 & 0.095 & 0.095 & 0.095 & 0.095 & 0.095 \\
\hline Hypothesis Verification & $\mathrm{H}_{0}$ & $\mathrm{H}_{0}$ & $\mathrm{H}_{0}$ & $\mathrm{H}_{0}$ & $\mathrm{H}_{0}$ & $\mathrm{H}_{0}$ \\
\hline
\end{tabular}


Table 6

Pearson correlation results of no adjustment for inflation

\begin{tabular}{ccccccc}
\hline \multirow{2}{*}{ Hypothetical } & \multicolumn{2}{c}{ Hypothesis 1 } & \multicolumn{2}{c}{ Hypothesis 2 } & \multicolumn{2}{c}{ Hypothesis 3 } \\
\cline { 2 - 7 } & $\begin{array}{c}\text { Personnel } \\
\text { cost }\end{array}$ & $\begin{array}{c}\text { Personnel } \\
\text { number }\end{array}$ & $\begin{array}{c}\text { Personnel } \\
\text { cost }\end{array}$ & $\begin{array}{c}\text { Personnel } \\
\text { number }\end{array}$ & $\begin{array}{c}\text { Personnel } \\
\text { cost }\end{array}$ & $\begin{array}{c}\text { Personnel } \\
\text { number }\end{array}$ \\
\hline Type of Relationship & Linear & Linear & Linear & Linear & Linear & Linear \\
\hline Std. Error & 0.05 & 0.05 & 0.05 & 0.05 & 0.05 & 0.05 \\
N & 102 & 102 & 102 & 102 & 102 & 102 \\
R & 0.005 & -0.003 & -0.219 & -0.261 & -0.051 & -0.061 \\
$\mathrm{R}^{2}$ & 0.00002 & 0.026 & 0.047 & 0.026 & 0.002 & 0.026 \\
P-value & 0.482 & 0.487 & 0.013 & 0.004 & 0.306 & 0.271 \\
Confidence Interval & 0.095 & 0.095 & 0.095 & 0.095 & 0.095 & 0.095 \\
\hline Hypothesis Verification & $\mathrm{H}_{0}$ & $\mathrm{H}_{0}$ & $\mathrm{H}_{1}$ & $\mathrm{H}_{1}$ & $\mathrm{H}_{0}$ & $\mathrm{H}_{0}$ \\
\hline
\end{tabular}

Table 7

Pearson correlation results of no adjustment for inflation

\begin{tabular}{ccccccc}
\hline \multirow{2}{*}{ Hypothetical } & \multicolumn{2}{c}{ Hypothesis 4} & \multicolumn{2}{c}{ Hypothesis 5} & \multicolumn{2}{c}{ Hypothesis 6} \\
\cline { 2 - 8 } & $\begin{array}{c}\text { fixed } \\
\text { assets }\end{array}$ & total assets & fixed assets & total assets & \multirow{2}{*}{ fixed assets } & total assets \\
\hline Type of Relationship & Linear & Linear & Linear & Linear & Linear & Linear \\
\hline Std. Error & 0.05 & 0.05 & 0.05 & 0.05 & 0.05 & 0.05 \\
$\mathrm{~N}$ & 102 & 102 & 102 & 102 & 102 & 102 \\
$\mathrm{R}$ & -0.012 & 0.000 & 0.022 & 0.085 & -0.032 & 0.062 \\
$\mathrm{R}^{2}$ & 0.0001 & 0.000 & 0.0004 & 0.007 & 0.001 & 0.003 \\
P-value & 0.450 & 0.499 & 0.412 & 0.198 & 0.376 & 0.270 \\
Confidence Interval & 0.095 & 0.095 & 0.095 & 0.095 & 0.095 & 0.095 \\
\hline Hypothesis Verification & $\mathrm{H}_{0}$ & $\mathrm{H}_{0}$ & $\mathrm{H}_{0}$ & $\mathrm{H}_{0}$ & $\mathrm{H}_{0}$ & $\mathrm{H}_{0}$ \\
\hline
\end{tabular}

\subsection{The First hypothesis testing (Personnel number and personnel cost)}

The findings of the study indicate that there are no relationships between the operational leverage and labor productivity index based on the personnel number and personnel cost with three criteria set forth in the research. There are also no relationship between the wholesale price index of goods and services without adjustment and the rate of inflation. The $\mathrm{H}_{0}$ hypothesis is confirmed, indicating that the lack of relationship among the mentioned items.

\subsection{The second hypothesis: Personnel number and personnel cost}

The findings of the study indicate that there are some meaningful relationship between the financial leverage and labor productivity index based on the number of employees and personnel cost with three criteria set forth in the research. There are some meaningful relationship between the wholesale price index of goods and services without adjustment and the rate of inflation. The H1 hypothesis is confirmed, indicating that relationship among the mentioned items.

\subsection{The third hypothesis: Personnel number and personnel cost}

The findings of the study indicates that there are no meaningful relationships between the compound leverage and labor productivity index based on the Personnel number and personnel cost with three criteria set forth in the research including the wholesale price index of goods and services without adjustment and the rate of inflation. The $\mathrm{H}_{0}$ hypothesis is confirmed, indicating that the lack of relationship among these figures. 
Table 8

Stepwise regression of multiple hypothesis testing

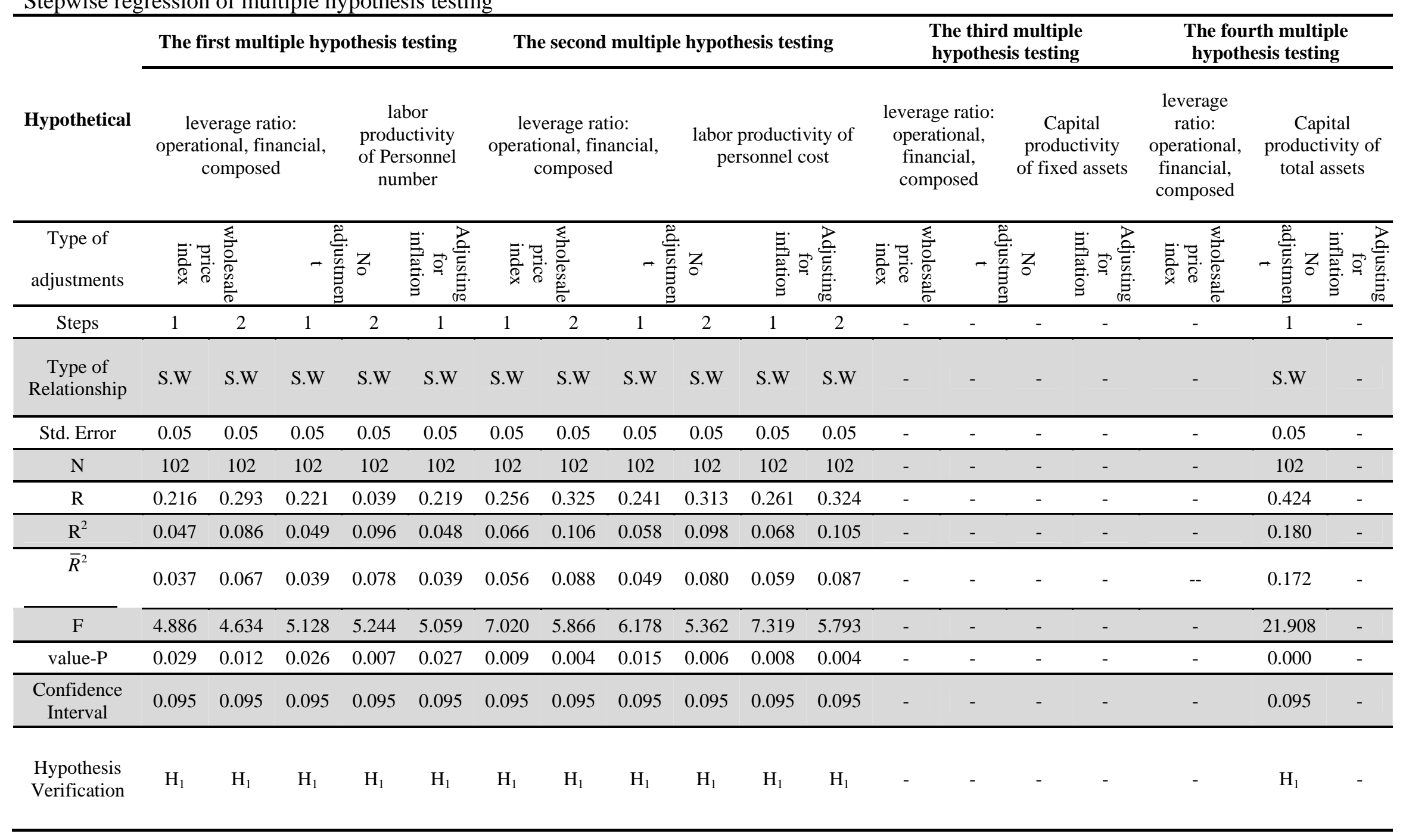




\subsection{The Forth hypothesis: fixed assets and total assets:}

The findings of the study indicate that there are not any relationship between the operational leverage and capital productivity index based on the fixed assets, and total assets with three criteria set forth in the research including the wholesale price index of goods and services without adjustment and the rate of inflation. The $\mathrm{H}_{0}$ hypothesis is confirmed, indicating that the lack of relationship

\subsection{The Fifth hypothesis: fixed assets and total assets}

The findings of the study indicate that there are some relationships between the financial leverage and capital productivity index based on the fixed assets with three criteria set forth in the research: the wholesale price index of goods and services without adjustment and the rate of inflation In this case, the $\mathrm{H}_{0}$ hypothesis is confirmed, indicating that the lack of relationship among the mentioned items. Also, there is a significant relationship when has not been used indication of any type (no adjustment). In this case, the hypothesis $\mathrm{H}_{1}$ that is expresses relationship is confirmed.

\subsection{The sixth hypothesis: fixed assets and total assets}

The findings of the study indicate that there are no relationship between the compound leverage and capital productivity index based on the fixed assets with three criteria set forth in the research: the wholesale price index of goods and services without adjustment and the rate of inflation. In this case, The $\mathrm{H}_{0}$ hypothesis is confirmed, indicating that the lack of relationship among the mentioned items. Also, there is a significant relationship when has not been used indication of any type (no adjustment). In this case, the hypothesis $\mathrm{H}_{1}$ that is expresses relationship is confirmed.

\subsection{The first multiple hypothesis testing}

The first multiple hypothesis testing: There is a significant relationship between leverage ratios and labor productivity indices according the personnel number. The findings of the study relationship leverage ratio and indicators of labor productivity in terms of personnel number and three criteria set forth in the study. Wholesale price index for goods and services without adjustment and the rate of inflation is briefly expressed as follows:

Adjusting the wholesale price index of goods and services is accomplished in two steps. In the first step, the financial leverage variable is entered into the equation because it has the most influence following that compound leverage variable entered the equation. The other variables have been removed from the equation because they have no effect. In this case, the multiple $\mathrm{R}$ value for financial leverage is equal to 0.216 , which indicates that this variable can be forecasted 0.216 labor productivity alone in terms of the personnel number. In addition, if also compound leverage is added, the amount of predictor will be 0.293 . Non-adjusted, have been carried out in two stages, the first step to financial leverage variable has entered the equation; because it has the most effective and subsequent compound leverage variable has entered the equation. The other variables did not have significant impacts and they were eliminated from the equation. In this case, the multiple $\mathrm{R}$ value for financial leverage is equal to 0.221, which indicates that this variable can be forecasted 0.221 labor productivity alone in terms of the personnel number. In addition, if compound leverage is added, the amount of predictor will become 0.039. Adjusted with rate of inflation made during one step, the first step to financial leverage variable has been entered the equation because has had the greatest effect, the other variables have been removed from the equation because they did not have any effect. In this case, the multiple $\mathrm{R}$ value for financial leverage is equal to 0.219 , which indicates that this variable can be forecasted 0.219 labor productivity alone in terms of the personnel number. 
Finally, the 0.095 confidence level and according to the significance level, adjusted wholesale price index of goods and services $(0.029,0.012)$ and no adjust; $(0.026,0.007)$ and adjust with rate of inflation; (0.027), there is a significant relationship between leverage ratio and indicators of labor productivity in terms of personnel number. Means $\mathrm{H}_{1}$ hypothesis that indicates exist relationship, is confirmed.

The Second multiple hypothesis testing: there is a significant relationship between leverage ratios and labor productivity indices according the personnel cost.

The findings of the study on relationship between leverage ratio and indicators of capital productivity in terms of personnel cost and three criteria set forth in the study is discussed here. First, wholesale price index for goods and services without adjustment and the rate of inflation is briefly expressed as follows,

Adjusting the wholesale price index of goods and services is performed in two stages. In the first stage, the financial leverage variable is entered into the equation because it has the most influence following that compound leverage variable entered the equation. The other variables have been removed from the equation because they had no effect. In this case, the multiple $\mathrm{R}$ value for financial leverage is equal to 0.256 , which indicates that this variable can be forecasted 0.256 labor productivity alone in terms of the personnel cost. In addition, if compound leverage is added, the amount of predictor will become 0.325. Non-adjusted, have been carried out in two stages, the first step to financial leverage variable has entered the equation; because it has the most effective and subsequent compound leverage variable was entered the equation. The other variables because had no effects and it was eliminated from the equation. In this case, the multiple $\mathrm{R}$ value for financial leverage is equal to 0.241 , which indicates that this variable can be forecasted 0.241 labor productivity alone in terms of the personnel cost. In addition, if compound leverage is added, the amount of predictor will become 0.313 . Adjusted with rate of inflation, have been carried out in two stages, the first step to financial leverage variable has entered the equation; because it has the most effective and subsequent compound leverage variable have entered the equation. The other variables had no effects and they were eliminated from the equation. In this case, the multiple $\mathrm{R}$ value for financial leverage was equal to 0.261 , which indicates that this variable can forecasted 0.261 labor productivity alone in terms of the personnel cost. In addition, if compound leverage is added, the amount of predictor will become 0.324. Finally, the 0.095 confidence level and according to the significance level, adjust the wholesale price index of goods and services $(0.009,0.004)$ and no adjust; $(0.015,0.006)$ and adjust with rate of inflation; $(0.008,0.004)$, there is a significant relationship between leverage ratio and indicators of labor productivity in terms of personnel cost. Means $\mathrm{H}_{1}$ hypothesis that indicates exist relationship, is confirmed.

\section{The third multiple hypothesis}

In multiple regressions, only variables were entered the equation that has been confirmed in previous hypothesis (correlation) found a significant relationship of them. Thus the test of Hypothesis 3 Is not used multiple regressions.

\section{The fourth multiple hypothesis testing}

Note that in the multiple regressions just variables were entered the equation that has been confirmed in previous hypothesis (correlation) found a significant relationship between them. There is a significant relationship between leverage ratios and capital productivity indices according the total assets. 
Based on the findings of the study, relationship leverage ratio and indicators of capital productivity in terms of total assets and one criteria set forth in the study. No adjustment is briefly expressed as follows,

Non-adjusted, made during one step, the first step to compound leverage variable has been entered the equation because has had the greatest effect, the other variables have been removed from the equation because they have no effect. In this case, the multiple $\mathrm{R}$ value for compound leverage is equal to 0.424 which indicates that this variable can be forecasted 0.424 capital productivity alone in terms of the total assets.

Finally, the 0.095 confidences level and according to the significance level, no adjust; (0.000), there is a significant relationship between leverage ratio and indicators of capital productivity in terms of total assets. Means $\mathrm{H}_{1}$ hypothesis that indicates exist relationship, is confirmed.

\section{Conclusions and Suggestions}

The results of the study have indicated that there were significant relationships between independent variables including leverage ratios with labor productivity. In addition, there was also a significance relationship between leverage ratios with capital productivity of total assets. Therefore,

1. According to the results, the leverage ratio and the productivity of labor and capital can be associated with each other. Therefore, disclosure the productivity could be considered in order to evaluate the performance of management in the company's financial statements.

2. Since specialized and efficient manpower play significant role in creating surplus value, and durability and survival of company, therefore, it is recommended that exchange company pay attention over the past properly trained staff and increase their information and technical knowledge.

3. Accounting standards and the theoretical concepts of financial reporting information are useful and could influence on financial decision making. Therefore, it seems that the financial statements must be prepared based on the facts for evaluation criteria of a company.

4. The study can repeated as a case study or for active companies in a particular industry and its results are compared with the results of this study.

5. Proper accounting system can affect the results of this study so it is suggested that this study is repeated in few companies with an appropriate accounting system, where components of financial statements prepared in accordance with accounting standards as the ideal way.

\section{References}

Akbari P., (2010a). A Study of the Relationship between Change in Productivity indices and Change in Financial Variables among Accepted Companies in Tehran Stock Market. Journal of Industrial Management if Islamic Azad University, Sanandaj branch, Iran

Akbari P., (2010b). An Investigation of the Relationship between Changes of Performance indices based on Productivity and Changes in Financial Variables Among accepted companies in Tehran Stock Market. The first International Conference of Economical Jihad2012 Kerman, Iran.

Akbari P., (2010c). An Investigation of the Relationship between Changes of Performance indices based on Productivity and Changes in Financial Variables Among accepted companies in Tehran Stock Market. The Master Business Management, Islamic Azad University, Kermanshah, Iran.

Ansari A.A.M., Karimi, M., (2009). THE Study of THE ability OF Internal Criteria of Management Performance Evaluation in Explanation of Value Creating FOR Shareholders. Accounting Research; 1(1), 112-129. 
AnvariRrostami A.A, Tehrani R, and Seraji H., (2004). Study The Relationships among EVA, EBIT, CFO and Share Market Value (MV): The Case of The Tehran Stock exchange (TSE). The Iranian Accounting and auditing Review Fall; 11(37), 3-22.

Azerbaijani K., Emadzadeh M, \& Arasteh M. (2007). Study the factor reducing the efficiency of TPM method in Iranit factories of Isfahan during the period 2002-2006. Journal of Quality, 4 (20), 65-56

Baharestan, J. (2007). An Investigation of the Relationship between accounting variables and indices of productivity in among accepted companies in Tehran Stock Market. (MA Thesis), Shahid Beheshti University, Tehran, Iran.

Brown D.P., \& Rowe B.J. (2007). The Productivity premium in equity returns. University of Wisconsin US. Retrieved from http://ssrn.com/abstract $=993467$

Central Bank of Iran. (2008). Yearly report of economic indicators, consumer of Commodity and services. Management of economic statistics, department of economic statistics, circle of economic indicators.

Davis E.P., \& Madsen J.B., (2008). Productivity and equity market fundamentals: 80 years of evidence for eleven OECD countries. Journal of International Money and Finance, 27 (8), 12611283

Eling, M., \& Michael L. (2009). Efficiency in the international insurance industry: A cross-country comparison. Journal of Banking \& Finance, 34 (7), 1497-1509

Etemadi, H., Mehrabi Kooshki, A., \& Ganji H. (2009). Relationships between labor productivity \& return on equity firms in Tehran Stock Exchange. Journal of Management Perspective, 33, 85103

Forastic, J. (1975). Productivity Prices and Wages. Paris O.E.E.C, European Productivity Agency, 12

Kendrick, J.W. (1993). Productivity Why Is Matters-How It is Measured? Productivity Measurement Improvement, Portland.

Lopez, J.R., \& Chacon, J.L.T. (2009).Technological sources of productivity growth in Japan, the U.S. and Germany. Working papers series, 1-38.

Rezaei, J., Faghih Nasiri, M., \& Tavakkoli Bghdadabad, M.R. (2009. Assessing total factor productivity change in the Tehran Stock Exchange by Using index of Tornqvist. Journal of Sustainable Growth and Development, 9(2), 122-103.

Rudolf, B., \& Zurlinden, M. (2009). Productivity and economic growth in Switzerland 1991-2005. Swiss National Bank. Working Papers, 1-31.

Samantha, D., \& Enserch., (1991). Productivity Awareness the U.S.A Survey of Major Cooperation. Industrial Engineering.

ShariatPanahi, S.M., \& Badavrnhndy, Y. (2004). Relationship between EVA of Refining the and stock returns adjusted on base risk. Journal of Accounting Studies, 2(7), 77-96.

Sinai, H.A., \& Ahmad, F. (2003). Study Relationship between productivity indices of labor and capital with Profitability indices in among accepted companies in Tehran Stock Market. Journal of Accounting Studies, 1(3), 95-125.

Tehrani, R. \& Khojasteh, M.A. (2008). Exploring the relationship between capital productivity and future stock returns and ITS effect on value and growth investment styles. Iranian Journal of management sciences, 3(11), 1-20.

Vander Eng, P. (2009). Total factor productivity and economic growth in Indonesia. Working Papers in Trade and Development, 1-45.

Vial, V.G. (2008). How much does turnover matter? Evidence from Indonesian manufacturing total factor productivity growth, 1975-95. Oxford Development Studies, 36(3), 295-322. 